\title{
Evaluating the Key Determinants of India's Energy Security and Overseas Equity Oil Investment
}

\section{Dulal Halder}

Ph.D. Research Scholar,

University of Petroleum and Energy Studies, Dehradun, India.

\section{Dr. Anshuman Gupta}

Professor, Dept. of Economics and International Business, UPES, Dehradun, India.

\begin{abstract}
In a span of about two decades, India has become the second fastest growing economy in the world after China. India has surpassed other Asian developing countries not only because of increases in inflows of foreign direct investment but also because of its potential to be a significant outward investor, including in the energy sector. With less than one percent of the world's oil and gas reserves, more than $80 \%$ of its oil requirement is imported. Overseas equity oil investment gradually emerged as a policy instrument of augmenting energy security. In the early 2000s, Indian national oil companies (NOCs) were encouraged by the Government to seek sourcing fossil fuels from abroad. While equity ownership ensures long-term supply security, they are complex and bring in strategic and geo-political considerations. Within India, there are demands for stronger diplomatic support. In this paper, the factors governing outward investment for equity oil are analysed in the context of an energy security framework with four vectors of Accessibility, diversity, reliability, and affordability.
\end{abstract}

Keywords:

Energy Security, Oil Demand and Supply, Overseas Equity Oil, Framework, diversity

\section{Theoretical Framework and Overseas Acquisitions}

The theoretical building blocks for equity oil acquisitions in foreign countries are drawn from a wide range of thematic areas like industrial economics, international business, finance, geo-political theories and strategic considerations within jurisdictions. The eclectic framework postulates that occurrence of cross-border mergers and acquisitions emerges from the existence of ownership of assets, globalization benefits and the dynamic relation between home country's structural changes and the economic 
development (14). According to industrial economics, a commercial enterprise strives for growth and expansion in two ways. The first is to enhance core competencies like developing new technologies, skill development, increasing managerial efficiency, creating joint ventures and global brand value creation. The other way to expand is to acquire or merge with another company/firm to achieve lead market position and to use the resources and expertise of the merged entity.

The literature review underlines that Indian overseas acquisitions possessed three major objectives - access to the international market, specific asset created by a larger company and supporting governmental objectives of strategic tie-ups for natural resources. Therefore, overseas acquisitions by Indian multinationals are directed with a set of multifaceted company-specific objectives (3). The literature review also highlights that Indian oil and gas companies engaged in overseas acquisitions are large, focussing on reserves acquisitions and equity oil production, but equally driven by governmental dictates (18).

This research paper, based on descriptive statistical analysis, aims to analyze the determinants of foreign oil resource acquisition by Indian State-owned Enterprises, also called National Oil Companies (NOCs). An international comparative approach examines the progress made by Indian NOCs in securing foreign energy resources and the prospects in that regard. Statistical data used in this paper are mainly from international energy organizations like BP Statistical Review, Ministry of Petroleum and Natural Gas and Indian NOCs. ${ }^{1}$ The erstwhile Planning Commission laid emphasis on expanding India's energy resource base to meet escalating demand and advocates overseas equity as one of the key elements of energy policy towards achieving energy security $(12,13)$. "Energy Security" is defined as a situation where energy supplies are available at all times in various forms at affordable prices and in sufficient quantities (UNDP). Taking a cue from this definition of energy security, the paper designs four vectors. This measure the key determinants and their impact on India's foreign energy acquisitions for energy security. The four vectors are Accessibility, diversity, reliability, and affordability. Under each vector, some specific determinants have been developed (Table 1).

\section{Brief Overview of India's Energy Quest overseas}

India's dependence on imported crude oil has a significant impact on energy security. The crude oil production of India during the year 2016-17 was at 36 Million Metric Tonnes (MMT) as against the production of 36.94 MMT in the previous year of 201516 , showing a decrease of $2.53 \%$ (4). Natural Gas production of India during the year 2016-17 was 31.89 Billion Cubic Meters (BCM) which is $1.09 \%$ lower than the production of 32.25 BCM in the previous year of 2015-16.

The gap between India's oil demand and supply is steadily widening with the oil demand reaching nearly 185 MMT in 2015-16 from the level of 138 MMT in 2009-

\footnotetext{
${ }^{1}$ Methodology has been defined in this para in broader terms
} 
$10^{2}$. Figure-1 indicates the historic demand-supply situation of oil in India, from which it becomes evident that with the demand-supply gap widening, and stagnant oil production within the country, higher imports has become inevitable. To this end, the Government of India has encouraged Indian national oil and gas companies to acquire equity stakes in foreign countries. As shown in Figure-2, India's indigenous oil production has been largely stagnant from2010-11 onwards whereas the consumption rose from 163 MMT to 203 MMT between 2010-11 to 2015-16.

\section{Accessibility}

The share of foreign equity oil in Indian oil consumption is an indicator of the impact of the overseas acquisition on India's energy security. As China's crude oil imports increased substantially from the level of $2.5 \mathrm{mb} / \mathrm{d}$ in 2005 to $6.7 \mathrm{mb} / \mathrm{d}$ in 2015 , its leaders sought to hedge against supply disruptions, mainly through investments in overseas oil (11). India followed China, albeit a little later. As indicated in Figure-3, Indian NOCs have made tremendous progress in securing equity oil from foreign countries. Equity oil acquired reached 17.80 MMT by 2016-17, over 200 times that of 2007. Accordingly, its proportion in India domestic production of oil and gas has risen to $18.9 \%$ by 2016-17. By 2030, equity oil production of India is projected to hit in excess of $60 \mathrm{MMT}$, accounting for 12 percent of India's oil consumption (6).

Despite the seemingly striking progress by Indian oil and gas companies, not all the equity oil produced abroad was shipped back to India (8). The majority of oil produced by Indian NOCs has been transacted in the international market due to the poor economic returns from processing sour crude oil. In terms of the prospect of securing equity oil in the short run, India would be in a stronger position to acquire foreign hydrocarbon assets. However, increased competition among oil importing countries and energy nationalism in the oil-producing countries may dampen long-term prospects(17).

Resource nationalism, potential risk, occurs with economic recovery, regime change and growing demand for oil and gas (12). Accessibility is susceptible to the intense competition among Asian economies that would further aggravate India's efforts to access foreign oil equities. For instance, China intends to expand its equity oil and gas production from overseas to 70 MMTOE by 2030 (10). Similarly, Japan and South Korea's foreign equity oil requirement would reach $40 \%$ and $35 \%$ of their crude imports, whereas that proportion was only $15 \%$ for Japan in 2007 and $4.1 \%$ for Korea (18).

\section{Diversity}

Popular opinion perceives the oil and gas industry focusing solely on exploration and Production assets, competitive advantage stemming from tangible assets, technical and project management capabilities, and intangible assets such as reputation and intellectual property rights (16). To gauge the impact of Indian foreign energy ventures on the country's energy security, this paper analyses equity oil acquisition

${ }^{2}$ Data source: Ministry of Petroleum and Natural Gas, Govt. of India 
with the following indicators: distribution by projects, distribution by investment in equity oil projects, and distribution of oil import sources of India.

India must engage energy-rich countries through energy diplomacy and foreign policy to ensure the accessibility of commercial energy at competitive prices (9). From the perspective of a number of overseas energy projects, ONGC Videsh Ltd. (OVL) is the leading Indian player in the international market (Table-2). Besides OVL, other CPSEs including Bharat Petroleum Corporation Ltd (BPCL), Indian Oil Corp (IOC), Oil India (OIL), GAIL and Hindustan Petroleum Corporation Limited (HPCL) have made considerable investments abroad in oil and gas assets.

Based on distribution by investment, NOCs have substantial investments in Russia, Mozambique, Brazil, and Sudan, indicating the growing importance of this continent to India's energy security (Table3). Among Indian overseas investments, Africa (22\%) and Russia (13\%) jointly account for $35 \%$.

Looking at import diversification, crude oil import from a single source is generally deemed far riskier than from multiple sources. This is primarily because a diverse group of suppliers, importers will be less vulnerable and shall not face a single hostage scenario (7).

Indian modern refineries are capable of handling a complex mixture of crude including sour and heavy crude, which offers these refiners opportunities to be globally competitive. Therefore, Indian refiners are consciously scouting for multiple sources to optimise refinery productivity thereby increasing the geographical spread of India's crude oil imports (Chart-1).

\section{Reliability}

Reliability is defined as the extent to which a country's energy supplies are exposed to various types of risks in its major foreign energy investment and import countries. The risks highlighted in this paper primarily consist of political risk (loss of investment returns from political instability), policy risk, transportation risk, and oil depletion risk.

As indicated in Table-2, India's equity oil investment is overwhelmingly concentrated in Russia, Latin America, Mozambique, and Sudan, while a major chunk of crude oil imports primarily come from Saudi Arabia, UAE, Iraq, and Kuwait. An analysis of risks will thus involve the geo-political situation and development in these countries. The Political risk, with India's exposed equity oil and oil imports, is mixed (2). At one end of low political risk are oil producing countries with good relations with India which could help promote India's energy security. At the other end of high political risk, countries like Sudan, Angola, and Nigeria are prone to internal conflicts.

Reliability banks on policy risk. It relates to the risk of loss of investment caused by changes in policies, such as tariffs, expropriation of assets, tax laws changes or restriction in repatriation of profits. The nationalisation wave in the Middle East and 
Latin America in the 1970s, with the accompanying oil price spikes, is an ideal example.

\section{Affordability}

Affordability can be measured in two ways - comparing the costs of acquiring equity oil and the costs of directly purchasing oil from the international market, and in terms of a country's GDP per capita growth relative to oil price fluctuations.

Asset prices of any commodity are functions of demand and supply. In addition to the demand growth from India and China, supply either was kept low by the oil cartel OPEC or was disrupted due to the conflict in the key oil-producing countries. The gap between demand and supply resulted in high oil prices upwards of $\$ 100$ per barrel by early 2014. This affected the economic situation in India as its oil import forex outgo ballooned. Higher oil prices from 2008-09 onwards encouraged enhanced oil exploration. North American shale oil and expanding Iraqi oil production led to a surplus in the global market (20). However, demand has decreased in Asia and Europe in recent months.

To that extent, it makes more depth to the discussions by taking account of world oil price levels and a host country's fiscal and taxation policies. Not only do different countries vary its policies on taxes and royalties, but also their policies for foreign equity participation in oil and gas vary periodically. For instance, Malaysia imposes a $10 \%$ royalty on oil and gas, while this rate is $20 \%$ in Saudi Arabia and $1-16.7 \%$ in Venezuela.

\section{Conclusion}

From the perspective of Accessibility, the Indian national oil companies have expanded overseas oil production significantly, since they embarked on foreign energy quest. India is a major economic growth centre that requires enhanced supplies, with a potential 8 to 10 percent yearly growth. However, despite onerous efforts, the accessibility of both equity oil and crude oil imports remain concentrated in select few countries.

While foreign energy quest may help mitigate India's energy security to some extent, but it needs complimentary efforts to promote energy conservation and intense policy drive to stimulate domestic exploration for oil and gas. The shale revolution in the USA is an apt example of augmenting energy security through domestic efforts. In the case of India, the shifting dynamics in global oil trade are expected to lend better bargaining power to a large oil buyer like India. This paper also brings out that ensuring fossil fuel resource security, we need to differentiate the international energy markets where it is easy to change the origin or destination of the trade from those in which the connection between supplier nations and buyer nations remain inflexible. 


\section{References}

[1]. British Petroleum, BP Statistical Review of World Energy. British Petroleum, London, 2016.

[2]. A. Chakrabarti and R. K, Arora, "India's Energy Security: Critical Considerations", Global Business Review, SAGE Publications http://gbr.sagepub.com2016

[3]. R. Chitoor. and D. Jena, "Understanding the overseas acquisitions of Indian Transnational Corporations", ISB Insight, 2013.

[4]. Directorate General of Hydrocarbons, Oil \& Gas Production \& Consumption Scenario in the Country, FY 2015-16.

[5]. Ernst \& Young Global Limited (2016). Portfolio management in oil and gas Building and preserving optionality.

[6]. International Energy Agency (IEA 2015), India Energy Outlook, World Energy Outlook Special Report, www.worldenergyoutlook.org/india

[7]. India's Dependence on Oil: The Oil Imports Strategies, IDSA, 2008

[8]. J. P. Pradhan, "Trends and Patterns of Overseas Acquisitions by Indian Multinationals", Institute for Studies in Industrial Development, New Delhi, 2007.

[9]. A.Mahajan, "Overseas Acquisitions of Energy Assets by India",https://www.greatlakes.edu.in 2010

[10]. M. N. Wing-Chu, "China's overseas oilfield acquisition strategy and its Implications", Reuters Fellowship Paper, Oxford University, 2007.

[11]. M. Meidan, "China's loans for oil: asset or liability", The Oxford Institute for Energy Studies, 2006,

[12]. N. Fueyo, A. Gómez, and C. Dopazo, "Multinational Enterprises: A Test of the Eclectic Paradigm", University of Leeds, Energy Security, Sustainability and Affordability in Asia Pacific, ADB Economics working paper series, No. 401, 2014

[13]. Planning Commission, "Indian Hydrocarbon Vision -2025", 2000.

[14]. Planning Commission, "The Integrated Energy Policy", 2006.

[15]. P. J. Buckley, N. Forsans and S. Munjal, Foreign Acquisitions by Indian, 2014.

[16]. R. Garcia, D. Lessard and Aditya Singh (September 2014). Strategic partnering in oil and gas: A capabilities perspective

[17]. B. K. Singh, "India's Energy Security: Challenges and Opportunities", Strategic Analysis, 34(6), $799-805,2010$.

[18]. Sujin Jeon, "Overseas Oil Development of South Korea", Oil Group, Strategy, and Industry Research Group, Seoul, South Korea, 2012.

[19]. WoodMackenzie, "Do oil and gas acquisitions create value? Insight,2016.

[20]. C. Pascual, "The New Geopolitics of Energy", Center on Global Energy Policy, Columbia, 133,2015 . 


\section{Table1: Four Indicators for India's Hydrocarbon Energy Security}
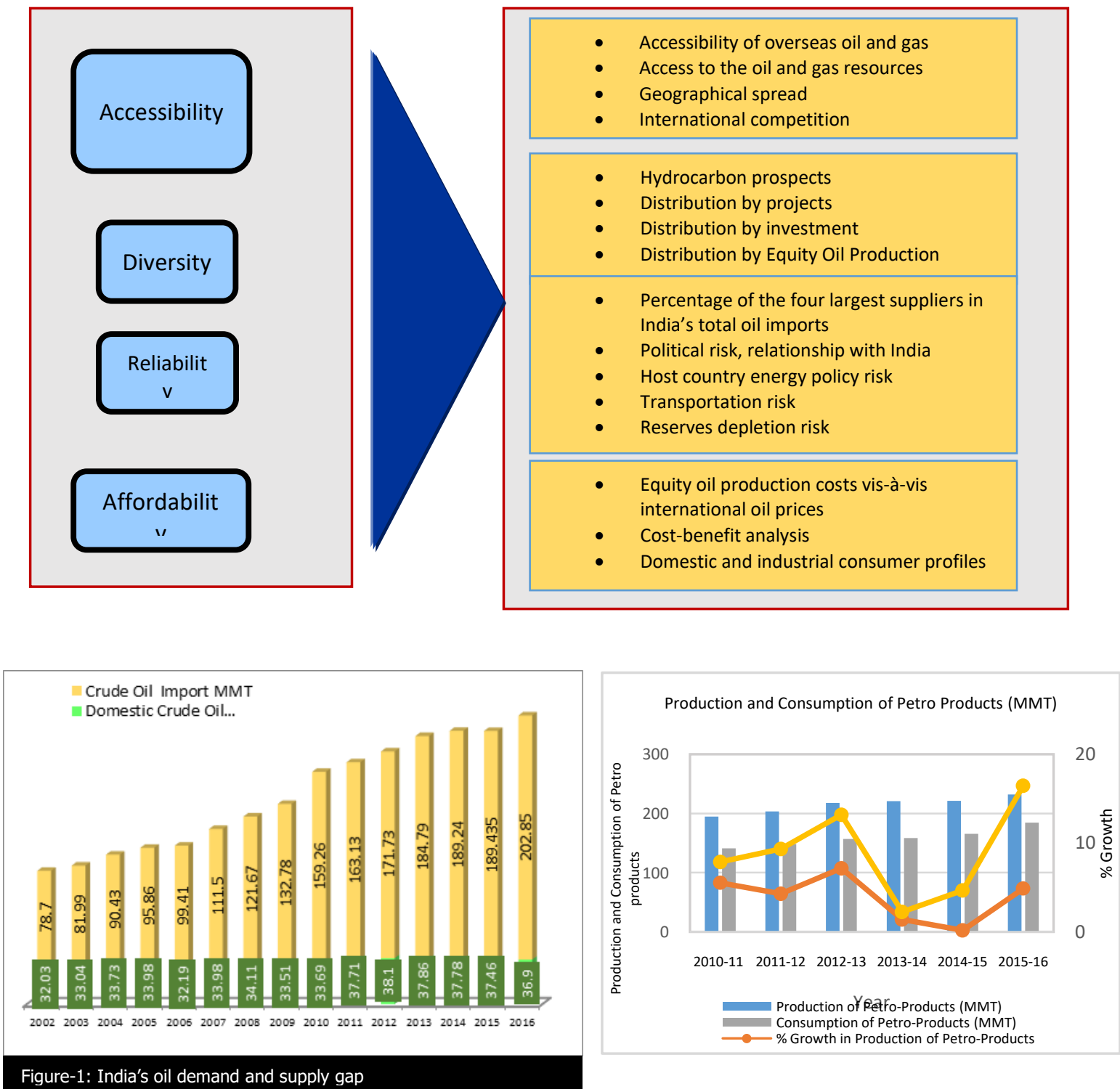

Figure-1: India's oil demand and supply gap
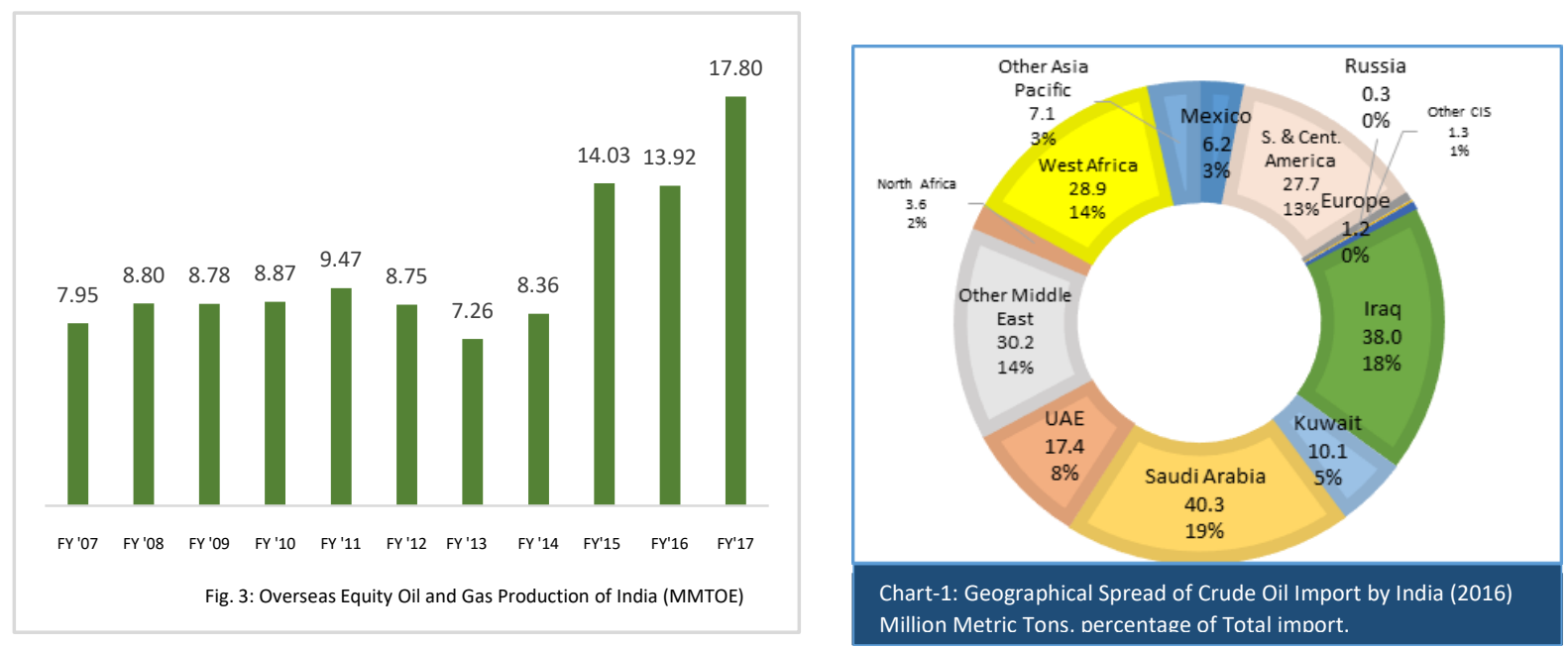

DOI: http://dx.doi.org/10.19085/journal.sijmd060301 
Table- 2: Distribution of Overseas Investments by Indian Oil Companies

\begin{tabular}{|c|c|c|c|c|c|c|c|c|c|c|c|}
\hline & $\begin{array}{l}\text { ONG( } \\
\text { Vides }\end{array}$ & & BPR & & $\mathrm{IOC}$ & & $\mathrm{OII}$ & & Tot & & Major Countries \\
\hline Geography & $\begin{array}{l}\text { No. } \\
\text { of } \\
\text { Proje } \\
\text { cts }\end{array}$ & $(\%)$ & $\begin{array}{l}\text { No. } \\
\text { of } \\
\text { Proj } \\
\text { ects }\end{array}$ & $(\%)$ & $\begin{array}{l}\text { No. } \\
\text { of } \\
\text { Pro } \\
\text { ject } \\
\text { s }\end{array}$ & $(\%)$ & $\begin{array}{l}\text { No } \\
\text { of } \\
\text { Pr } \\
\text { oje } \\
\text { cts }\end{array}$ & $(\%)$ & $\begin{array}{l}\text { No. } \\
\text { of } \\
\text { Pro } \\
\text { ject } \\
\text { s }\end{array}$ & $(\%)$ & Major Countries \\
\hline Africa & 7 & 17.5 & 1 & 10 & 3 & $3 \% .5$ & 4 & 37 & 15 & 22 & $\begin{array}{l}\text { Libya, Sudan, } \\
\text { South Sudan, } \\
\text { Mozambique, } \\
\text { Namibia, Gabon, } \\
\text { Nigeria }\end{array}$ \\
\hline $\begin{array}{l}\text { Middle } \\
\text { East }\end{array}$ & 6 & 15 & & & 2 & 25 & 1 & 9 & 9 & 13 & $\begin{array}{l}\text { Syria, Iraq, Iran, } \\
\text { Israel, UAE, Oman }\end{array}$ \\
\hline Russia & 3 & 9.5 & 2 & 20 & 2 & 25 & 2 & 18 & 9 & 13 & Russia \\
\hline $\begin{array}{l}\text { CIS and } \\
\text { Europe }\end{array}$ & 2 & 5 & & & & & & & 2 & 3 & $\begin{array}{l}\text { Azerbaijan, } \\
\text { Kazakhstan }\end{array}$ \\
\hline $\begin{array}{l}\text { South East } \\
\text { Asia and } \\
\text { Far East }\end{array}$ & 11 & $2 \% .5$ & 1 & 10 & & & 2 & 18 & 14 & 20 & $\begin{array}{l}\text { Vietnam, } \\
\text { Bangladesh, } \\
\text { Myanmar, } \\
\text { Indonesia, East } \\
\text { Timor, New } \\
\text { Zealand, Australia }\end{array}$ \\
\hline $\begin{array}{l}\text { North } \\
\text { America }\end{array}$ & & & & & & & 1 & 9 & 1 & 1 & USA \\
\hline $\begin{array}{l}\text { Latin } \\
\text { America }\end{array}$ & 11 & $2 \% .5$ & 6 & 60 & 1 & 12.5 & 1 & 9 & 19 & 28 & $\begin{array}{l}\text { Venezuela, } \\
\text { Colombia and } \\
\text { Brazil }\end{array}$ \\
\hline In Total & 40 & $\begin{array}{l}100 \\
\% \\
\end{array}$ & 10 & $\begin{array}{l}100 \\
\% \\
\end{array}$ & 8 & $\begin{array}{l}100 \\
\% \\
\end{array}$ & 11 & $\begin{array}{l}100 \\
\%\end{array}$ & 69 & $\begin{array}{l}100 \\
\%\end{array}$ & \\
\hline
\end{tabular}

Source: Company websites and Annual Reports (2016-17) 
Table-3Distribution by overseas acquisition Investment 1995-2016 (Million US\$)

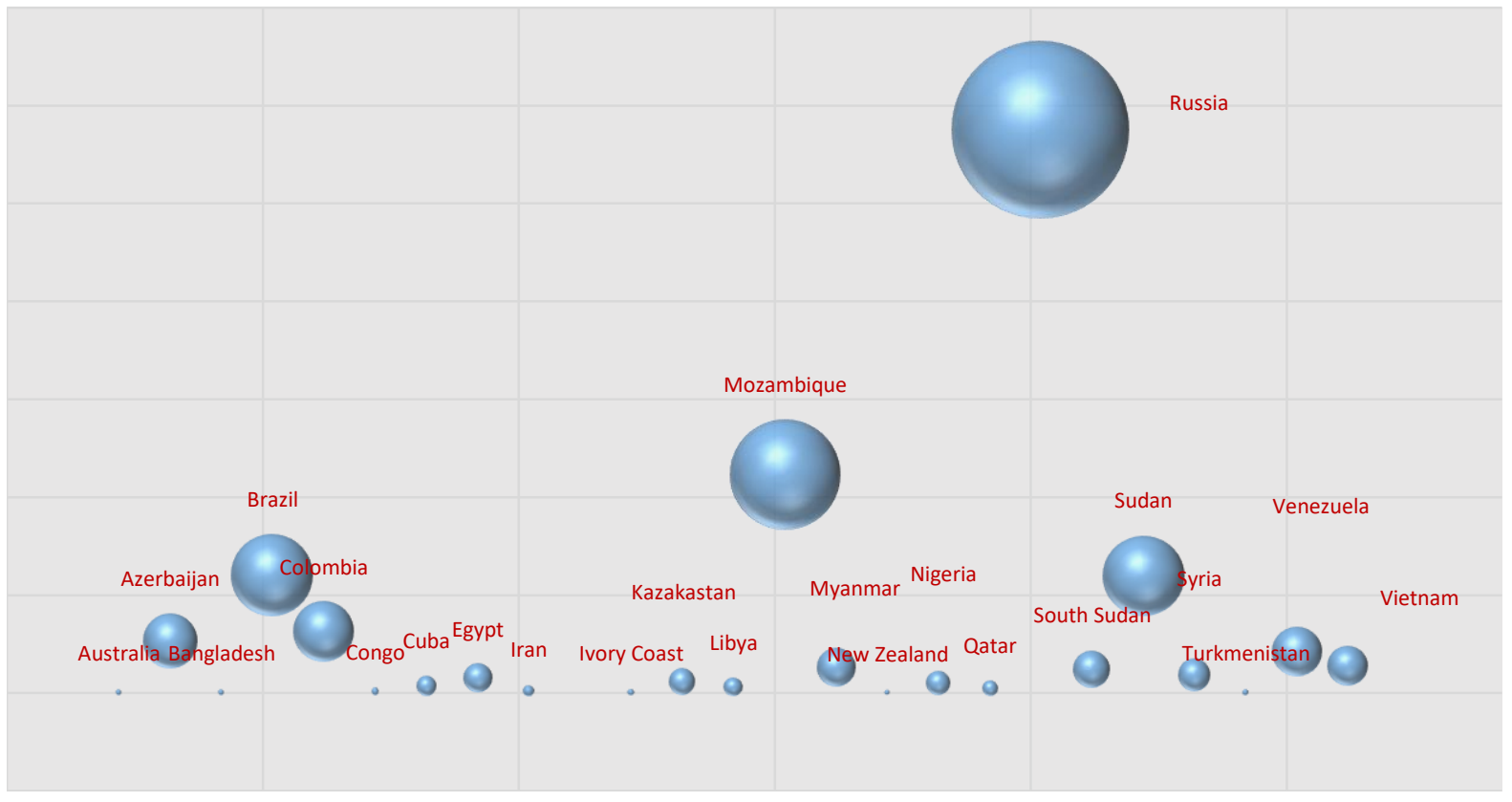

Data Source: Annual Reports and Investors Presentation (2017-18) of OVL, BPCL, IOC and Oil India 